\title{
Catholic Action, the Second Vatican COUNCIL, AND THE EMERGENCE OF THE New Left in El Salvador (1950-1975)
}

I

n 1958, Roque Dalton, a young poet affiliated with the Communist Party of El Salvador (PCS), won the first prize in a poetry contest at the University of El Salvador. A few days later, members of Salvadoran Catholic University Action, a student organization known as ACUS or simply Catholic Action, published a demolishing but carelessly written critique of Dalton. 'The anonymous writer of an article titled "Under the Empire of Vulgarity" turned his disgust with the poem written by Dalton into a diatribe against Dalton's political persona. ${ }^{2}$ Dalton's raw allusions to double standards in the sexual morality of priests and his remarks about the Catholic practice of fasting seem to have especially upset the leaders of ACUS. ${ }^{3}$ A month later, ACUS published a rejoinder written by Dalton, along with excerpts of the controversial poem. In his retort, Dalton stated that ACUS dodged debates on substantial political and aesthetic issues by engaging in "insults, quick and facile judgments, and rude pigeon-holing that closes all means of intellectual comprehension."

I am deeply thankful to former members of ACUS-JEC, CRAC, the PDC, the PCS, the ERP, and the FPL for sharing their memories of these crucial events in conversations we held in El Salvador during the past eight years. Thanks to Eric Zolov and the outside reviewer for their insightful editorial contributions to this article. I am grateful to Rafael Flores and Rubén Ortiz from the Historical Archive of the Archbishopric of San Salvador, who granted me access to sources on ACUS-JEC, to Verónica Guerrero and Jacqueline Morales de Colocho from the Biblioteca P. Florentino Idoate, S.J. of the Central American University "José Simeón Cañas" in San Salvador and to Manuel Sorto for facilitating images for this article, to Vijay Prashad, Zayde Gordon Antrim, Seth Markle, and Dario Euraque, my former colleagues at the International Studies Program at Trinity College, and to Laura Hostetler, Kevin Schultz, Chris Boyer, Ralph Keen, and other colleagues at the Department of History at the University of Illinois at Chicago for their institutional support, which enabled my to write this article.

1. In 1949, Catholic students founded La Agrupación Cultural Universitaria Salvadoreña (The Salvadoran Cultural University Association), which was renamed Salvadoran Catholic University Action (ACUS) in 1954. Letter of the Junta Directiva of ACUS to Monseñor Luis Chávez y González, San Salvador, circa 1954.

2. "Bajo el imperio de la vulgaridad," ACUS Pax Christi in Regno Christi, July 23, 1958.

3. ACUS Pax Christi in Regno Christi, August 31, 1958.

4. "Comentando una nota: carta de Roque Dalton a los editores de ACUS," ACUS Pax Christi in Regno Christi, August 31, 1958. 
What is telling about this episode between the ACUS intellectuals and Dalton, who were about the same age and came from similar social and educational backgrounds, is their obviously contrasting aesthetic and political sensibilities. But more importantly, this exchange shows that the leaders of ACUS took seriously their self-appointed role as arbiters and defenders of "decency" and "honor" in university life. ACUS publications often warned about the threat posed by an emerging "materialist morale in different orders of life" and called on Catholics to "safeguard their faith against the [anti-Catholic] prejudice skillfully promoted" by Marxists. ${ }^{5}$ Although ACUS is virtually unknown outside Catholic Church circles in El Salvador, it had a major impact in the political history of that country. Some of its members founded the Christian Democrat Party (PDC) in 1960 and, later, in the early 1970s, two insurgent organizations: the Revolutionary Army of the People (ERP) and the Popular Liberation Forces-the FPL Farabundo Martí. Together, these constituted the backbone of the Farabundo Martí National Liberation Front (FMLN), an insurgent coalition that fought a 12-year war against the Salvadoran regime between 1980 and 1992 .

This article examines the roles that Catholic Action intellectuals played in the foundation of the New Left in El Salvador. ${ }^{6}$ It ponders how and why they adopted innovative approaches on religion and politics that constituted a rupture with a long-standing conservative Catholic tradition in El Salvador. I argue that the radicalization of the young Catholic Action intellectuals was an unexpected result of the cataclysmic theological transformations experienced by the Catholic Church in the 1960s. From an institutional viewpoint these transformations were intended to preserve the traditional influence of the Catholic Church in Latin America. ${ }^{7}$ Instead, they enabled the convergence between Catholic intellectuals and members of revolutionary movements who sought a structural transformation of capitalism. ${ }^{8}$ Catholic intellectuals assimilated, often uncritically, the new theology of the Catholic Church formulated by the Second Vatican Council (1962-1965) and the Second Conference of Latin American Bishops (CELAM) held in 1968, which they learned through highly scripted pedagogical processes at a time

5. "Editorial," ACUS Pax Christi in Regno Christi, August 31, 1958.

6. The term "New Left," in this context, designates a set of emerging social and political movenents that played major roles in the mobilizations of the 1960s and 1970s, some of which led to the founding of insurgent organizations like the ERP and the FPL. Leaders of social movements, Catholic intellectuals as well as Communist Party dissidents became key figures of the New Left. The concept "New Left" is particularly useful to differentiate this generation of activists from academics, working-class intellectuals, and activists associated with the Communist Party of El Salvador (PCS) who generally embraced electoral politics until 1977.

7. Christian Smith, The Emergence of Liberation Theology: Radical Religion and Social Movement Theory (Chicago: The University of Chicago Press, 1991), pp. 72-79.

8. Michael Löwy, The War of Gods (London: Verso, 1996), pp. 4-31. 
of epochal political and institutional changes. ${ }^{9}$ These changes included the growing polarization of Salvadoran society and politics in the context of the 1960s Cold War, a major reform at the University of El Salvador between 1963 and 1967, and the mobilizations of students in the United States, France, Mexico, and elsewhere. The new theological leadership of the Catholic Church formulated a radical critique of the core principles and ideology of liberal capitalism, the colonial past, and "new forms of colonialism." It also undermined traditional Catholic anti-Marxist attitudes, and it legitimized the use of revolutionary violence against tyranny, echoing the Christian doctrine of the "Just War." 10 These theological notions were crucial in inspiring the young Catholic Action intellectuals who formed the New Left insurgency in the early 1970s. The changing political and religious mentality of this cohort was also informed by what Michael Löwy calls the "negative affinity" between "the Catholic ethic and capitalism." "Catholic anti-capitalism" might be rooted in "the ethical and religious identification of Christ with the poor" and communal traditions in Catholic Church history. " Catholic Action in El Salvador increasingly embodied an anti-capitalist ethos at the time of the Second Vatican Council and in the years following. This emerging anti-capitalist culture influenced the increasing political and intellectual exchanges between Catholic and Marxist university students and scholars at the University of El Salvador, Catholic institutions, and political parties. This confluence between Catholic and Marxists intellectuals, starting in the mid 1960s, shaped the political cultures of the New Left prior to the emergence of liberation theology.

The roles that Catholics played in the mobilizations of the 1970s and 1980s in El Salvador have been widely analyzed. Studies on progressive Catholicism in El Salvador have focused on prominent figures like the slain archbishop Oscar Arnulfo Romero; priests like José Inocencio Alas, Rutilio Grande, and Miguel Ventura; the Jesuit scholars at the Central American University (UCA); the Christian Base Communities (CBCs); and more recently on El Castaño, a Catholic education center that trained peasant catechists who joined the ERP insurgency in Morazán. ${ }^{12}$ But despite the ubiquity of Catholic Action intellec-

9. See Documentos Completos del Vaticano II (Bilbao: Mensajero, 1966); Juan Ramón Vega, Las 54 cartas pastorales de Monseñor Chávez (San Salvador: Arzobispado de San Salvador, 1997); and Andrés Opazo B., "El movimiento religioso popular en Centroamérica: 1970-1983," in Movimientos populares en Centroamérica (San Jose: EDUCA, 1985), pp. 166-167.

10. Smith, The Emergence of Liberation Theology, pp. 125, 126, and 159. The doctrine of the "Just War" generally posits that the objective of such war "should be to vindicate justice and restore peace." See Roland H. Bainton, Christian Attitudes Toward War and Peace: A Historical Survey and Critical Re-evaluation (Nashville: Abingdon Press, 1985 [1960]), pp. 14, 15, 37, and 44.

11. Löwy, The War of Gods, pp. 4-31.

12. Phillip Berryman, The Religious Roots of Rebellion (New York: Orbis Books, 1984); Jon Sobrino, Ignacio Martín-Baró, and Rodolfo Cardenal, eds., La voz de los sin voz: la palabra viva de Monseñor Romero, 7th ed. (San Salvador: UCA Editores, 2007 [1980]); Anna L. Peterson, Martyrdom and the Politics of 
tuals in the formation of the New Left, their multiple contributions to these movements have rarely been considered in the academic literature. ${ }^{13}$

The decrees of the Second Vatican Council changed in fundamental ways "Catholics' understandings of themselves, both as men and women within the church and in relation to the larger society." 14 In the case of El Salvador, scholars have examined the impact of the Second Vatican Council on the pastoral work conducted by the archbishopric of San Salvador and its reverberations within the Catholic hierarchy and among top Catholic intellectuals like the Jesuit Ignacio Ellacuría. ${ }^{15}$ The sociologist Juan Ramón Vega asserts that a Church reform led by San Salvador archbishop Luis Chávez y González in the 1950s actually preceded the council. The council's decrees ratified the Church reform conducted by Chávez y González and encouraged him to disseminate the council's documents among laypeople, priests, and nuns. The archbishop also penned several pastoral letters inspired by the work of the council, particularly "On the Responsibility of Laypeople over the Ordering of the Temporal" issued on August 6, 1966, which steered the country's public opinion for several months and generated a strong reaction among the Salvadoran elites. ${ }^{16}$ Catholic Action intellectuals who formed the New Left, like most sectors of the Salvadoran Catholic Church, experienced crucial ideological transformations in this period as they examined the council's documents and increasingly realized the personal and collective challenges implicit in its conclusions. ACUS and other Catholic Action groups incarnated the socially committed theology of the council, breaking with the ritualistic and conservative Catholicism that prevailed in El Salvador in the 1960s. ${ }^{17}$

The history of El Salvador during the 1960s Cold War was relatively unexplored until recently. Scholars writing about the origins of the country's civil war have examined this period only in passing. They offer similar narratives on

Religion: Progressive Catholicism in El Salvador's Civil War (Albany: State University of New York Press, 1997); Teresa Whitfield, Paying the Price: Ignacio Ellacuria and the Murdered Jesuits of El Salvador (Philadelphia: Temple University Press, 1994); Leigh Binford, "Peasants, Catechists, Revolutionaries: Organic Intellectuals in the Salvadoran Revolution, 1980-1992," in Landscapes of Struggle, Aldo Lauria-Santiago and Leigh Binford, eds. (Pittsburgh, Pa.: University of Pittsburgh Press, 2004), Pp. 105-125; and Jeffrey Gould and Charles R. Hale, "Utopías menores en América Central en la segunda mitad del siglo XX," Asociación para el Fomento de los Estudios Históricos en Centroamérica: April-June 2012), http://www.afehc-historia-centroamericana.org/, accessed October 30, 2013.

13. Juan Ramón Vega, Las comunidades cristianas de base en America Central (San Salvador: Arzobispado de San Salvador, 1987), pp. 74, 75.

14. Kathleen Sprows Cummings, "Teaching about Women, Gender, and American Catholicism," in The Catholic Studies Reader, James T. Fisher and Margaret M. McGuinness, eds. (New York: Fordham University Press, 2011), p. 226.

15. Vega, Las comunidades cristianas, pp. 71-74; Teresa Whitfield, Paying the Price, pp. 29, 30; and Anna L. Peterson, Martyrdom and the Politics of Religion, pp. 48-53.

16. Juan Ramón Vega, Las 54 cartas pastorales, p. 3; and Las comunidades cristianas, p. 72.

17. Vega, Las comunidades cristianas, p. 75. 
the failure of the Alliance for Progress (ALPRO) program in El Salvador, which was implemented by the governments of Presidents Julio A. Rivera (1962-1967) and Fidel Sánchez Hernández (1967-1972) and the Party of National Conciliation (PCN)-the official party-to transform the country's highly polarized socioeconomic structure and to conduct democratic reforms. ${ }^{18}$ According to Walter LaFeber, El Salvador became "the pride of the Alliance [for Progress]" in the 1960s. "[Presidents] Kennedy and Johnson ensured that it received more Alliance funds ( $\$ 63$ million between 1962 and 1965) than any other Central American country." In 1964, notes LaFeber, the CIA called it "one of the hemisphere's most stable, progressive republics." 19 It was during President Rivera's tenure that the United States first became a dominant actor in Salvadoran politics through the execution of the ALPRO program, which sought to contain the influence of the Cuban Revolution in Central America; it combined modernization, a limited political liberalization, and counterinsurgency. More to the point, ALPRO in El Salvador encompassed an economic restructuring that featured industrialization as well as labor and education reforms. Politically, it aimed at the creation of an alternative "third way" between Marxist revolution and right-wing dictatorship, which required the legalization of opposition parties like the PDC and the introduction of proportional representation at the National Assembly. ALPRO's influence was matched by the expansion of the state security apparatus through the formation of the Nationalist Democratic Organization (ORDEN), which was a vast paramilitary network, and the Salvadoran National Security Agency (ANSESAL), a centralized intelligence agency. ${ }^{20}$

During the 1960s, El Salvador experienced rapid industrialization and high rates of economic growth, becoming a major actor in the Central American Common Market (CACM) created under the auspices of ALPRO. But the power of the landed oligarchy that had traditionally dominated the Salvadoran economy and politics remained intact at the end of that decade. ${ }^{21}$ While the Salvadoran elites accumulated massive wealth during the ALPRO epoch, hunger grew in the countryside as "the oligarchs drove peasants and tenant farmers off their plots to obtain new land" in their efforts to expand the booming sugar

18. James Dunkerley, The Long War: Dictatorship and Revolution in El Salvador, 2nd ed. (London: Verso, 1985), pp. 75-76; Tommie Sue Montgomery, Revolution in El Salvador: From Civil Strife to Civil Pcace (Boulder, Colo.: Westview Press, 1995), pp. 54-56; Stephen G. Rabe, The Killing Zone: The United States Wages Cold War in Latin America (New York and Oxford, U.K.: Oxford University Press, 2012), p. 165; and Walter LaFeber, Inevitable Revolutions: The United States in Central America, 2nd ed. (New York and London: W. W. Norton, 1993), pp. 173-178.

19. Walter LaFeber, Inevitable Revolutions, pp. 174-175.

20. Tommic Sue Montgomery, Revolution in El Salvador, p. 54; and James Dunkerley, The Long War, pp. 76-79.

21. James Dunkerley, The Long War, p. 53. 
production in the 1960s. "By 1969, 300,000 Salvadorans-one in every eight citizens - had fled this 'model' Alliance nation to find food and work in neighboring Honduras." 22 The political liberalization implemented by President Rivera from 1962 onward came to an end during the repressive government of President Arturo A. Molina (1972-1977), as the country sunk into a deep socioeconomic and political crisis after the brief but devastating war between El Salvador and Honduras in July 1969; that war generated nearly 100,000 Salvadoran refugees and caused the collapse of the CACM. ${ }^{23}$ The most enduring legacy of the ALPRO era was the creation of a counterinsurgent state that comprised ANSESAL, the army, the security forces, ORDEN, and armed illegal groups ("death squads") like La Mano Blanca (the White Hand), which callously repressed the rising social movements and opposition parties throughout the 1960s and 1970s. LaFeber, Dunkerley, Montgomery, and Rabe concur that ALPRO ultimately failed to alter El Salvador's extremely polarized agrarian society and to promote democratic reforms ${ }^{24}$ LaFeber wrote a lapidary statement that summarized this view: "The decade of the Alliance ended in El Salvador as the decade of revolution began. The country that Johnson believed to be the 'model' for the Alliance became instead a model for violent Central American revolutions." ${ }^{25}$ More recently Héctor Lindo-Fuentes and Erik Ching have studied the ramifications of modernization and development theories on the education reform conducted by PCN governments, challenging previous assessments of the Salvadoran state in the 1960s and 1970s that had portrayed the ruling elites and high-ranking military as a repressive and quasi-monolithic bloc that simply echoed U.S. Cold War anticommunism. ${ }^{26}$

Scholars writing on the emergence of the New Left insurgency in El Salvador often privilege the roles that Communist and Christian Democrat dissidents played in this process. They attribute the creation of the New Left to the internal crises of the PDC and the PCS in the late 1960s. Both parties failed to convince the radicalized youth that made up their rank and file to continue their participation in electoral politics, despite the recurrent electoral frauds and the intensification of state terror conducted by the PCN governments. ${ }^{27}$ Scholars have emphasized the agency of Salvador Cayetano Carpio and other former commu-

22. Walter LaFeber, Inevitable Revolutions, pp.176-177.

23. Montgomery, Revolution in El Salvador, pp. 59-67; James Dunkerley, The Long War, pp. 80-86; and Paul D. Almeida, Waves of Protest: Popular Struggle in El Salvador, 1925-2005 (Minneapolis: University' of Minnesota Press, 2008), pp. 70-102.

24. Dunkerley, The Long War, pp. 75-76; Montgomery, Revolution in El Salvador, pp. 54-56; Rabe, The Killing Zone, p. 165; and LaFeber, Inevitable Revolutions, pp. 173-178.

25. LaFeber, Inevitable Revolutions, pp. 178.

26. SHéctor Lindo-Fuentes and Erik Ching, Modernizing Minds in El Salvador: Education Reform and the Cold War, 1960-1980 (Albuquerque: University of New Mexico Press, 2012), pp. 19-20.

27. Dunkerley, The Long War, p. 87; and Montgomery, Revolution in El Salvador, p. 102. 
nist leaders who created the FPL and ascribed the foundation of the ERP to dissidents of the Communist Party youth and young Christian Democrats who initially founded El Grupo, a guerrilla cell, and later the ERP. ${ }^{28}$ Departing somewhat from this narrative, Yvon Grenier claims that most scholars specializing on this topic have overlooked the contributions of the politicized Catholic middle class (that is, students at the UCA and the Externado de San José, a Jesuit high school in San Salvador), and "various Catholic youth and lay organizations" to the "emergence and development of the insurgency."29 Cynthia McClintock shares the views on the origins of the New Left insurgency formulated by most specialists on this subject but adds that "relative to the leaders of the FPL, the founders of the ERP were younger, more middle class, and usually formerly affiliated with the Christian Democrat Party rather than with the PCS." 30

In recent years, historians have shown a renewed interest in the trajectory of the Latin American New Left. Eric Zolov, for instance, advocates a broader definition of the notion "New Left," one that includes not only the New Left insurgencies of the 1960s but also the eclectic conjunctions of student organizations, political groups, and countercultural movements-particularly Latin American rockeros (youth influenced by rock culture) who posed a nonviolent radical challenge to political and social conventions. ${ }^{31}$ To a certain extent the countercultural sensibilities of the 1960s also informed the emergence of the New Left in El Salvador as poets, artists, performers, and musicians who embraced social activism or avant-garde aesthetics joined this movement. Literary groups such as La Generación Comprometida (The Committed Generation) and La Masacuata had a particularly strong resonance in the formation of the New Left. However, I posit that the fundamental contribution of social Catholicism to the rise of the New Left in that country has been underestimated in the scholarship. My research examines the porous boundaries between social Catholicism, youth culture, social movements, and insurgencies during the 1960s and 1970s.

The Cuban Revolution, Christian Democracy, and Cold War crises in El Salvador centrally informed the politicization of Catholic Action intellectuals in the 1960s. From the beginning of that decade, they accused Fidel Castro of

28. Montgomery, Revolution in El Salvador, pp. 103-104; Yvon Grenier, The Emergence of Insurgency in El Salvador: Ideology and Political Will (Pittsburgh. Pa.: University of Pittsburgh Press, 1999), pp. 42, 67; Timothy P. Wickham-Crowley, Gucrrillas and Revolution in Latin America: A Comparative Study of Insurgents and Regimes since 1956 (Princeton, N.J.: Princeton University Press, 1992), pp. 211, 219-221, and 224-225; and Hugh Byrne, El Salvador's Civil War: A Study of Revolution (Boulder, Colo., and London: Lynne Rienner Publishers, 1996), p. 34.

29. Grenier, The Emergence of Insurgency in El Salvador, pp.134, 135.

30. Cynthia McClintock, Revolutionary Movements in Latin America: El Salvador's FMLN and Pcru's Shining Path (Washington, D.C.: United States Institute of Peace Press, 1998), pp. 49-5I .

31. Eric Zolov, "Expanding Our Conceptual Horizons: The Shift from an Old to a New Left in Latin America," A Contracorricnte 5:2 (Winter 2008), pp. 47-73. 
promoting a violent anticlericalism in Cuba and contributed to the emergence of the PDC as a leading opposition party, which they viewed as a reformist alternative to social revolution in El Salvador. As the country's political turmoil intensified in the late 1960s, members of ACUS and its sister organization, Catholic Student Youth (JEC), joined radical student movements at the university inspired by the new Catholic theology and the countercultural sensibilities of that period. In contrast with the prevalent narratives on the origins of the New Left insurgency in El Salvador, I contend that the majority of founders of both the ERP and the FPL were in fact members of a cohort of middle-class students affiliated with Catholic Action. While dissident Communist Party leaders and activists played an important role in the creation of these movements, they constituted a small minority in the ranks of the first guerrilla organizations. In the case of the FPL, for example, few Communist dissidents aside from Carpio remained active during the 1970s. Instead, I suggest that a precocious generation of university students affiliated with Catholic Action, who came of age between 1967 and 1972, constituted the critical mass of the nascent New Left insurgency. This cohort constituted a "rupture generation" that engaged in a long-term frontal struggle against the authoritarian regime.

Although most members of this generation had conservative Catholic family backgrounds and educations, their radical politics were informed by the rise of the social movements in El Salvador and the general climate of rebellion against capitalism and colonialism in the late 1960s. They led a student movement that featured an unprecedented practice of direct democracy at the university; built multiple connections with similar movements in Central America, Mexico, France, Spain, and other countries; challenged the Communist Party's hegemony in university politics; and faced head-on the oligarchic-military regime through its radical activism. They also participated in pedagogical processes promoted by the Catholic Church, which enabled the first interactions between peasant leaders and university students; these led in turn to the expansion of the New Left insurgencies into rural areas. Unlike previous generations of ACUS intellectuals who were usually affiliated with the PDC and considered upward social mobility to be compatible with social activism and reformist politics, the Catholic Action youth of the late 1960s became the first generation of "professional revolutionaries" that emerged from the ranks of the Salvadoran Catholic middle class. Members of this generation fully embraced revolutionary lives, in the context of the growing confrontations between the social movements, the opposition parties, and the state at the height of the Cold War in Latin America.

In what follows I ponder the sinuous transformation of ACUS from a conservative student organization of the 1950s into the cradle of the New Left insur- 
gency in the late 1960s. The first section examines the emergence of Catholic Action between 1949 and 1962, its peculiar Cold War anticommunism, and the roles that some of its affiliates played in the formation of the PDC. The second scrutinizes the theological and political changes experienced by Catholic Action intellectuals at the time of the Second Vatican Council. The third explores the creation of the New Left in the context of the university reform and the rise of countercultural movements between 1963 and 1972 . The fourth and last section briefly traces the insurgents' attempts to draw on the Christian doctrine of the "Just War" to form alliances with Catholic peasant communities-alliances that constituted the bastion of the insurgency in the 1970s and during the civil war.

\section{ORIGINS OF ACUS (1949-1962)}

When Abraham Rodríguez, a high-school graduate from San Miguel, arrived in San Salvador to study law in 1948, strong anti-Catholic sentiments prevailed at the University of El Salvador. Since 1949 students like Rodríguez had sought to create a Catholic political movement at the university, despite the opposition of students affiliated with the PCS who generally considered the Catholic Church a retrograde institution closely allied with the Salvadoran elites and the government of President Oscar Osorio (1950-1956). ${ }^{32}$ Amid the intellectual and political activity of the moment, Rodríguez joined ACUS, aided by the Jesuit priest Isidro Iriarte, the rector of the San José de La Montaña Seminary.

Iriarte was particularly concerned about the absence of well-versed Catholic intellectuals at the constitutional assembly sponsored by President Osorio, which produced the country's first democratic constitution in 1950. To address this issue, he wanted to replicate the experience of the Cuban Catholic Church, which had trained several generations of Catholic university intellectuals since the 1930s. Iriarte advocated the creation of ACUS among the Church hierarchy, but warned them that they should not harbor illusions about quick successes in their pastoral work among university students. Forming a new generation of Catholic intellectuals at the university, according to Iriarte, was "not a matter of days or weeks but of years." 33

ACUS was a specialized branch of Catholic Action, an international movement that endorsed a French theological and philosophical body of thought known

32. Drawing on Mexico's PRI and Peronismo, Osorio promoted the modernization of El Salvador in the context of U.S. Cold War anticommunism. 1950.

33. Letter from Padre Isidro Iriarte to Monseñor Luis Chávez y González, San Salvador, August 18, 
as "integral humanism" or "Social Christianity." Catholic philosopher Jacques Maritain formulated Social Christianity in the 1930s and 1940s, largely as a response to the declining influence of Catholicism among the working classes in France and Belgium. Social Christianity inspired the creation of Christian Democrat parties and Catholic Action in Europe, and it first came to Latin America during the 1930s through the collaboration of the Vatican, Latin American bishops, and religious orders, all of whom wanted to counter the growing influence of secular ideologies (especially socialism and communism) among working-class and university intellectuals. ${ }^{34}$ Social Christianity constituted an "alternative vision of the social order" and a radical critique of "unrestrained capitalism," which challenged the dominance of conservative sectors within the Catholic Church prior to the Second Vatican Council. ${ }^{35}$

Catholic Action implemented a worldwide strategy to form Catholic intellectuals and workers. It created various organizations of university and highschool students, peasant youth, and workers, and formulated a pedagogy called "To see, to judge, and to act." This method comprised the depiction of the working and living conditions of the socially excluded, the analysis of such conditions "in light of Christian principles," and the definition of actions to "realistically ... correct or enhance their milieu." Catholic Action was an influential movement in Brazil, Argentina, Chile, Venezuela, and Uruguay. It also set the basis for the foundation of Christian Democrat parties, and it "nurtured a whole generation of Catholic leaders" who became important political and intellectual figures in those countries. ${ }^{36}$ In the 1950s and 1960s it was a well-established program in Central America, particularly in Guatemala and El Salvador. Deborah Levenson-Estrada studied the trajectory of the Catholic Worker Youth (JOC), a branch of Catholic Action, "in working class neighborhoods" of Guatemala City. JOC activists played key roles in the reorganization of Guatemalan trade unions in the aftermath of the 1954 CIA coup against President Jacobo Arbenz. ${ }^{37}$ In El Salvador, ACUS and JEC were particularly influential among middle-class students at the university and in high schools.

In the 1950s, ACUS was a conservative student organization that operated at the University of El Salvador, which served roughly a thousand students. It promoted a reformist anticommunist ideology, which gained considerable leverage among the mostly middle-class students, despite the fierce opposition of PCS

34. Smith, The Emergence of Liberation Theology, pp. 77, 80.

35. Opazo B., "El movimiento religioso popular en Centroamérica: 1970-1983," p. 165.

36. Smith, The Emergence of Liberation Theology, p. 81.

37. See Deborah Levenson-Estrada, Trade Unionist Against Terror: Guatemala City, 1954-1985 (Chapel Hill: University of North Carolina Press, 1994), pp. 80-104. 
affiliates to Catholic activism. ${ }^{38}$ Members of ACUS designated themselves "university apostles" whose main mission consisted in promoting Christian values in leading sectors of society and "consciousness among Catholic university students about [their] responsibility and presence in the modern world." ${ }^{39}$ In the 1950s leaders of Catholic Action were still echoing the Rerum Novarum (New Times), an encyclical sanctioned by Pope Leo XXIII in 1891 that considered liberalism and Marxism two manifestations of Western materialism at odds with Catholic theology. They believed that nineteenth-century liberalism had created massive social exclusion (that is, proletarians) in Europe and elsewhere and chastised communism as a form of "collective materialism" that brought grave "social and religious" consequences in countries where it prevailed. Catholics were committed to redeem proletarians, not necessarily by adopting a "middle way" between liberalism and communism, but by assuming "a firm equilibrium on justice." In this vein, Catholic Action called on "moderate Catholics" to promote long-overdue social transformations in the country. ${ }^{40}$

ACUS fully embraced the Cold War anticommunism prevalent in El Salvador in the 1950s. It showed particular concern for the Soviet persecution of nationalists and Catholics in the Eastern Bloc. Catholic Action students strongly condemned the execution of Hungarian leaders Imre Nagy and Pal Maleter ordered by Nikita Khrushchev in June 1958, calling it "a new bloody page, written with traces of barbarism and cruelty ... in the shameful annals of the Soviet Union." "41 They labeled the Soviet Union a tyrannical regime that curtailed religious freedoms in Poland and deemed Catholicism a major deterrent of communism in Eastern Europe. They ultimately described the Cold War as a decisive battle for the survival of "Western Christian civilization." 42 Communism, according to Catholic Action, constituted an unprecedented challenge to Christianity that embodied "a spirit of absolute violence," one that could not be "crush[ed] through brute force" but only "through a more powerful spiritual force." 43 But in contrast with their preoccupations about the future of the democracy in distant Eastern Europe, ACUS leaders seemingly ignored the anticommunist crackdown ordered by President Osorio in 1952, which targeted hundreds of political opponents, public intellectuals, labor leaders, and students who advocated democratic rule in El Salvador. They also overlooked the 1954 CIA coup against the democratically elected president

38. "Cómo nació la ACUS," Boletín de la ACUS (May 1950).

39. Junta Directiva of ACUS to Monseñor Luis Chávez y González, San Salvador, circa 1954.

40. "Materialismo he ahí el enemigo," ACUS Pax Christi in Regno Christi, circa January 1961.

41. Editorial in ACUS Pax Cbristi in Regno Cbristi, July 23, 1958.

42. Stefan Wilkanowicz and Zophia Wlodek, "Algunos aspectos sobre los problemas educativos actuales en Polonia," ACUS Pax Christi in Regno Christi, July 23, 1958.

43. ACUS, "Guerra y Paz," ACUS Pax Christi in Regno Christi, August 31, 1958. 
Jacobo Arbenz in neighboring Guatemala, a stand that was consistent with their anticommunism and the active role that the Catholic hierarchy and middle-class Catholic students in Guatemala played in the ousting of Arbenz. This is all the more notable because the coup against Arbenz was a crucial event in the "radicalization of continental politics" in the $1950 \mathrm{~s} .{ }^{44}$ It motivated young leftists in Latin America to engage in more militant responses to authoritarianism and U.S. involvement in the region. ${ }^{45}$

The year 1960 was crucial in the history of the Cold War in Central America as the United States vigorously fought the real and imagined aftershocks of the Cuban Revolution in the region. The impact of the CIA coup against President Arbenz in Guatemala among university intellectuals in El Salvador had been limited, but the ousting of Venezuelan dictator Marcos Pérez Jiménez in January 1958 and the Cuban Revolution of January 1959 inspired a new wave of mobilization in San Salvador against the authoritarian government of President José María Lemus (1956-1960). ${ }^{46}$ In October 1960, an unlikely coalition made up of faculty at the University of El Salvador and military officers loyal to former President Osorio deposed Lemus after he ordered a crackdown against the university community with the purported objective of containing a Cuban-sponsored plot against his government. The Civic Military Junta that replaced Lemus outlined an ambitious plan for the democratization of El Salvador-the demilitarization of the state and the restoration of civic and political rights, including the right to organize independent political parties. The junta also promoted electoral reforms and planned to conduct democratic elections in 1962. The U.S. government granted diplomatic recognition to the junta in December 1960, but only after U.S. diplomats in San Salvador and at the U.S. State Department had debated the merits of this decision for several weeks. But apparently, the junta's determination to maintain diplomatic relations with Cuba despite U.S. efforts to expel Fidel Castro's regime from the inter-American system sealed its fate. Army officers backed by the United States toppled the junta in a violent coup in January of 1961 and installed a reactionary Civic Military Directorate, which immediately broke diplomatic relations with Cuba. ${ }^{47}$

However, during the political opening created by the Civic Military Junta, Catholic intellectuals founded the PDC, which became a decisive player in Sal-

44. Greg Grandin, The Last Colonial Massacre: Latin America in the Cold War (Chicago and London: The University of Chicago Press, 2004), p. 5.

45. Ibid.

46. Víctor Valle, Siembra de vientos: El Salvador 1960-69 (San Salvador: CINAS, 1993), pp. 42-47.

47. See Joaquín M. Chávez, "The Pedagogy of Revolution: Popular Intellectuals and the Origins of the Salvadoran Insurgency, 1960-1980" (Ph.D. diss., New York University, 2010), pp. 41-73. 
vadoran politics in the following three decades. Members of ACUS, reformist Catholic intellectuals, and affiliates of the Confederation of Latin American Christian Trade Unions (CLASC) founded the PDC in November 1960. According to Héctor Dada, who was then a member of ACUS, the foundation of the PDC and its "brutally anti-oligarchic" discourse generated anxieties among a range of political actors, including the PCS, U.S. government agencies, ultraconservative sectors of the Catholic Church, and the Salvadoran oligarchy itself. The communists deemed the creation of the PDC a U.S. government machination to undermine their influence among trade unions. The latter feared that the emergence of the Christian Democrats as an independent political force might debilitate the staunchly anticommunist oligarchic-military regime in El Salvador. The Salvadoran military and the elites viewed the Christian Democrats as a serious threat because they mobilized noncommunist middle-class intellectuals, as well as priests, teachers, and peasant leaders. ${ }^{48}$

In the aftermath of the Cuban Revolution and the transformative events of 1960 and 1961 in El Salvador, ACUS intellectuals were convinced that the highly polarized Salvadoran society faced a crucial dichotomy between "evolution and revolution." Despite their intense rejection of Fidel Castro and the Cuban Revolution, Catholic intellectuals depicted 1961, the year that the Civic Military Directorate took power in the bloody coup sanctioned by the Kennedy administration, as the " 25 th hour" to conduct social reforms to avert violent revolution in El Salvador. ${ }^{49}$ Because of their anticommunist rhetoric, Catholic intellectuals called instead for revolution "under the Empire of Law." They claimed that the Catholic Church approved social revolution, without fomenting "violence, genocide, and class struggle as atheist communism proposes and practices." 50

Catholic Action intellectuals viewed the PDC as a viable alternative for carrying out a nonviolent social revolution in El Salvador and decisively joined its ranks in the 1960s. During that decade, they drew on President Eduardo Frei's "Revolution in Freedom" in Chile (1964-1970) and the Christian Democrat tradition in Venezuela represented by Rafael Caldera and the Comité de Organización Política Electoral Independiente (COPEI) to devise a reformist program that positioned the PDC as the leading opposition party in the country. At that time members of ACUS became PDC activists, often as popular educators linked to Catholic Church pedagogical initiatives or as community organizers working with the municipal government of San Salvador under the first Christian Democrat major of the city, José Napoleón Duarte.

48. Héctor Dada, interview by Joaquín Chávez (April 23, 2007).

49. "Ante un nuevo peligro," ACUS Pax Christi in Regni Christi, circa March 1961.

50. “Revolución o evolución,” ACUS mimeograph, circa March 1961. 


\section{Transformation of Catholic Action (1962-1965)}

On October 11, 1962, some 10,000 people of "all social strata" attended a "procession-vigil" in San Salvador to celebrate the start of the Second Vatican Council. In the following three years, Archbishop Chávez y González personally organized working groups of priests and laypeople to discuss the council documents, particularly Gaudium and Spes or "The Pastoral Constitution of the Church and the Modern World," sanctioned in 1965. ${ }^{51}$ This document unambiguously declared that the Catholic Church had the foremost responsibility to side with the poor and the weak. Gaudium and Spes also appealed to the clergy and laypeople in developing nations to engage in ecclesiastical practices that addressed the renewed social concern of the Catholic Church. ${ }^{52}$ ACUS intellectuals, like many other Salvadoran Catholics, experienced fundamental theological and political changes as a result of their examinations of the council's documents and interactions with priests and bishops cognizant of the new theology.

In 1964, Catholic Action started a process of ideological renewal under the guidance of two Belgian priests committed to the new Catholic theology. The arrival of Esteban Alliet and Jan De Planck, two clerics sponsored by the dioceses of Bruges and the University of Louvain to serve as Catholic Action's new ecclesiastic advisors, was a turning point in the renovation of the organization. Their innovative pastoral work among the Catholic Action youth revitalized the organization and changed its negative image among the student population. Ignacio Paniagua, a former medical student who joined Catholic Action in 1964, recalled that at that time Catholic middle-class students generally had "very limited political baggage and little consciousness of social problems." Paniagua also remembered his initial skepticism about joining Catholic Action, an organization secular students usually considered reactionary. However, after meeting Alliet, Paniagua changed his mind. He recalled that Alliet did not wear a cassock and talked openly about the political participation of Catholics, social justice, and solidarity. ${ }^{53}$ At that time, Catholic Action, like its Latin American counterparts associated with the International Movement of Catholic Students (MIEC; based in Medellín, Colombia) and Pax Romana, were heavily invested in an effort to influence ongoing university reform on the continent, invoking the Second Vatican Council decrees. ${ }^{54}$ Catholics in El Sal-

51. See José Inocencio Alas, Iglesia, tierra y lucha campesina: Suchitoto, El Salvador, 1968-1977 (San Salvador: Asociación Equipo Maíz, 2003), pp. 41-45.

52. Peterson, Martyrdom and the Politics of Religion, p. 48.

53. Ignacio Paniagua, interview by Joaquín Chávez (July 20, 2007).

54. “Informe de la Delegación de ACUS Asistente al Segundo Seminario Latinoamericano de Pax Romana MIED celebrado en Lima del 14 al 28 de abril de 1963, Tema: Reforma Universitaria en América Latina," mimeograph, San Salvador, May 1963. 


\section{Figure 1 \\ Delegates to the IX Inter-American Congress on Catholic Education, San Salvador, 1967}

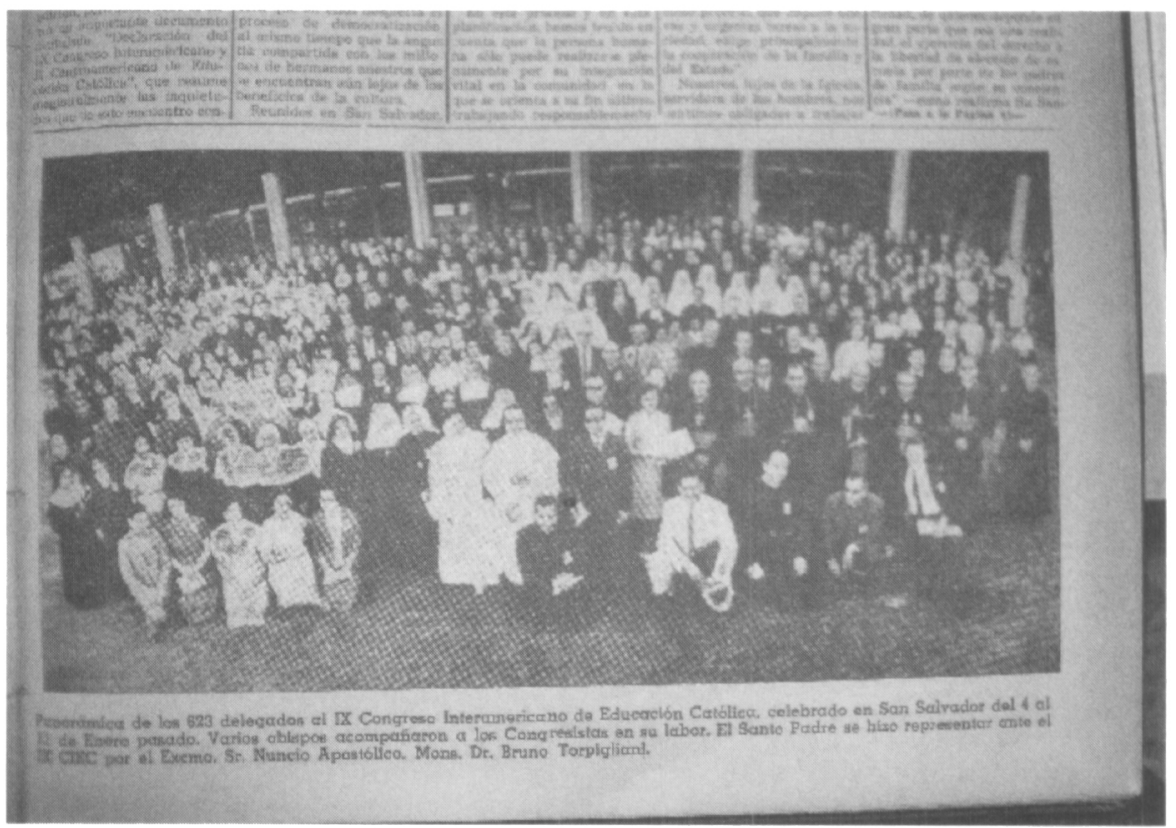

This image shows a panoramic view of the 623 delegates to the IX Inter-American Congress on Catholic Education, held in San Salvador in January 1967. Several bishops joined the delegates in their labor. The Apostolic Nuncio Monsignor Doctor Bruno Torpigliani represented Pope Paul VI at the congress. Source: Orientación, San Salvador, January 15, 1967. Courtesy of the Historical Archive of the Archbishopric of San Salvador.

vador organized numerous events to discus the council teachings during the late 1960s (see Figure 1).

Priests, bishops, and members of Catholic Action reflected at length on the meaning of the Second Vatican Council for the university community. In a series of workshops and seminars, they discussed the multiple dimensions of the new Catholic theology. They debated a variety of topics, including pastoral work among university students, popular education, development, and agrarian reform. Bishop Arturo Rivera y Damas, a participant in the council meetings in Rome, and other members of the Church hierarchy met frequently with Catholic Action students and affiliates of the Movement of Catholic Intellectuals, a lesser-known group led by Guillermo Manuel Ungo, a social democrat intellectual formerly associated with ACUS, to discuss theological issues 
related to the council. ${ }^{55}$ The legitimacy of violent resistance against tyranny implicit in the new Catholic theology was particularly controversial among the Catholic hierarchy. Bishop Marcos McGrath from Panama, a towering figure at the 1968 Second Conference of Latin American Bishops held in Medellín, Colombia, commented on the Church stand on this issue, citing Pope Paul VI's encyclical Populorum Progressio ("On the Progress of Peoples") while lecturing Salvadoran Catholic students. A few months later, a conservative Salvadoran cleric accused McGrath of fomenting "a theology of violence." McGrath responded that he was interested solely in promoting "peaceful development" based on popular education. He stated that he had never preached "a theology of violence" as the cleric claimed but had only paraphrased the teachings of Paul VI that sanctioned the use of "violence as the last resort" in the face of tyrannical regimes. McGrath wrote emphatically: "And it is necessary to underline the word 'last' with great insistence." Indeed, he argued that Catholics needed "clearer theological principles that can orient those who feel tempted by violence." ${ }^{56}$ McGrath's assertiveness on this matter reveals his concern about the danger that hasty interpretations of the new theology might encourage priests and laypeople to join guerrilla movements. After all, Camilo Torres Restrepo, a Colombian priest who joined the insurgent National Liberation Army (ELN) and was killed by the Colombian military in 1966, was an influential figure among Catholic intellectuals in El Salvador at that time..$^{57}$

Esteban Alliet, the Belgian advisor of Catholic Action, also ruminated on the relevance of the new theology for Catholic students. During a seminar with members of Catholic Action held in La Palma, Chalatenango, in 1967, Alliet suggested that the social teachings of Pope Paul VI and the council were not necessarily a new theology but rather a return to the roots of Christianity-that is, a search for the "true ideology and mission" of the Catholic Church, which ostensibly consisted in serving humanity, particularly the dispossessed, with a selfless and "humble attitude of love." The encyclical of Pope Paul VI titled "On the Progress of Peoples" advocated the right of "equal participation" in society and the solution to "the physical and intellectual undernourishment" of the dispossessed, and not simply a technocratic approach aimed at increasing their levels of income. This meant that Catholic Action students had to envision practical ways to enhance the labor conditions of peasants and workers. "It is an evangelization of action but both had to complement each other.

55. Orientación, "Reunión para preparar Día de Acción Católica," July, 1, 1967.

56. "Fray Fuentes Castellanos es inexacto en sus críticas a Monseñor McGrath: carta de Monseñor McGrath a Monseñor Luis Chávez y González," Orientación, May 26, 1968.

57. Orientación, "Camilo Torres Restrepo: quinto aniversario de su muerte (febrero 1929-15 de febrero de 1966, asesinado brutalmente)," February 1971. 
Whoever just talks but does not act, is not convincing; but whoever just acts without meditating, acts wrongly." This type of social activism also required conscientious planning, or in the words of Alliet "a true spirit of efficacy." Members of ACUS had to carefully plan their activities, "to know what is the most urgent [task] to solve and to find the more just and effective means to achieve it." Alliet, like McGrath, also discussed the issue of violence as the last resort to fight tyranny, alluding to Paul VI's encyclical. He added that once the decision to use violence as a method of self-defense had been made, it should be practiced "in a precise, planned and decisive" way. Ultimately he believed that Catholic middle-class youth should play a fundamental role in the transformation of the social inequalities that characterized Latin American societies in the 1960 s. ${ }^{58}$

Evoking the Second Vatican Council documents, Catholic Action members increasingly embraced an anti-capitalist ethos that moved away from the moralistic questioning of liberalism inspired in Rerum Novarum and Quadragesimo Anno ("Fortieth Year"), two influential encyclicals among Catholic intellectuals in the early 1960s. Ignacio Paniagua recalled that his views on private property changed after the council. In the past, Paniagua said, he had regarded private property as "inviolable," but after studying the council documents he thought that "the common good and the right to land and life" should prevail over it. In the late 1960s, Paniagua and other members of ACUS regularly met with students of medicine affiliated with the PCS to discuss the potential convergence between the Marxist left and progressive Catholics at the University of El Salvador. ${ }^{59}$ The frontal attacks on the ethics of capitalism embraced by Catholic intellectuals after the council weakened their traditional antagonism toward the Marxist left, enabling these first dialogues.

\section{UNIVERSITY REForm AND THE RISE OF THE NEW LeFT}

The emergence of the New Left in El Salvador had multiple foci and actors. It encompassed the entangled trajectories of student, teacher, and worker movements, literary groups, rock and folk bands, and political groups associated with the Catholic Church like Catholic Action and the PDC, as well as dissident Communist Party leaders. However, the university was by and large the main locus for the creation of the New Left insurgency. The multiple institutional, social, ideological, and political transformations generated by the university reform between 1963 and 1967 often motivated affiliates of

58. See Orientación, "El progreso de los pueblos y la universidad," October 23-29, 1967.

59. Ignacio Paniagua, interview by Joaquín Chávez (July 20, 2007). 
Catholic Action to reconsider their roles in the changing university milieu and Salvadoran society. The university reform led by Rector Fabio Castillo, a professor of medicine, aimed at "raising [the] scientific quality" of higher education to meet "the challenges that economic modernization posed [to the production of] knowledge." At the time of the reform, heated "social, political, economic, and cultural" debates on the country's future took place at the university campus in San Salvador. Numerous studies published during this period advocated "structural changes" aimed at improving the living conditions of peasants and urban workers. ${ }^{60}$ The reform changed the university from an academic institution that served almost exclusively upper-middleclass students into a center of learning with a growing and socially diverse student body. The student population, which included not only students from San Salvador but also from cities and towns across the country, increased from a thousand in 1960 to roughly 17,000 by the early 1970s. The reform also achieved major renovations in academic programs, teaching methods, research, administration, and infrastructure. ${ }^{61}$ A salient feature of the reform was the creation of a two-year general studies program called Areas Comunes (General Studies) that incoming students were required to complete as a precondition for admission to a university department. The young Catholic Action students entering the university became leaders of a powerful student movement organized first in Areas Comunes between 1967 and 1970; this was the Committee of Representatives of General Studies, better known as CRAC, "the Onomatopoeic Voice of Rupture." 62

The General Studies program created by the university reform was "the nursery of the Salvadoran guerrillas," according to Rafael Velásquez, a former university student who joined the ERP in the early 1970s. Velásquez remembered that the founders of the insurgency were for the most part student activists in Areas Comunes. ${ }^{63}$ Students enrolled in Areas Comunes elected classroom representatives who collectively formed CRAC. Through its practice of direct democracy this organization mobilized thousands of Areas Comunes students, who in fact constituted the majority of the student population at the university. ${ }^{64}$ Among the affiliates of JEC, ACUS's sister organization, were students from elite Catholic high schools in San Salvador who later became top insurgent leaders; Rafael Arce Zablah, Joaquín Villalobos, Virginia Peña Men-

60. See FLACSO El Salvador and Fundación "Dr. Manuel Gallardo," Prensa clandestina: El Salvador 1970-1975 (San Salvador: FLACSO El Salvador and Fundación "Dr. Manuel Gallardo," 2011), p.109.

61. Manuel Luis Escamilla, "La reforma universitaria de El Salvador: breve discusión doctrinaria" (San Salvador: Universidad de El Salvador, 1967), p. 37.

62. Victoria Ramírez, interview by Joaquín Chávez (October 10, 2006).

63. Rafael Velásquez, interview by Joaquín Chávez (March 22, 2007).

64. See Diagnóstico global de la Universidad, Tomo I (San Salvador: Universidad de El Salvador, 1972), pp. 119,120 , and 125 . 
doza, Ana Margarita Peña Mendoza, Felipe Peña Mendoza, Ana Sonia Medina, and Alejandro Solano, initially were leaders of CRAC. ${ }^{65}$

The political and cultural gap between members of CRAC and students and faculty associated with the PCS (the "Old Left") grew steadily as the former began to exude greater defiance and express stronger anti-dogmatism. They plainly rejected attempts to "indoctrinate them using Soviet manuals," an effort purportedly conducted by Jorge Arias-Gómez, a lawyer-historian affiliated with the PCS, and other Communist intellectuals at the University. ${ }^{66}$ Francisco Jovel, a former leader of CRAC who later became a top FMLN commander, summarized the collision between the PCS and the emerging New Left as follows:

With all the events that came to bear on the debate, namely, the ANDES strike, Tlatelolco, May in France, the urban guerrillas in the Southern Cone, the [1969] War between El Salvador and Honduras, Vietnam, and the hippie movement, it was not an optimal environment to indoctrinate students when rebelliousness prevailed against docility. ${ }^{67}$

CRAC leaders viewed themselves as an integral part of the "Latin American Left" (that is, the Latin American New Left) allied with the Cuban Revolution in contraposition to the PCS, which they considered a dogmatic pro-Soviet organization. CRAC activists drew abundantly from dependency theory (a paradigm formulated by Latin American sociologists and economists that explicates the historical origins of Latin American underdevelopment, which they had studied with Argentine sociologists teaching at the university in the time of reform) to formulate alternative revolutionary theories to those of the PCS. They were closely linked to student movements in France, North Vietnam, Mexico, and Spain and actively supported the revolutionary left in Central America and the Southern Cone. CRAC leaders considered the experiences of the Tupamaros from Uruguay, the Left Revolutionary Movement (MIR) from Chile, and the urban guerrillas led by Carlos Marighela in Brazil to articulate a new revolutionary strategy in El Salvador. They also supported the Fuerzas Armadas Rebeldes (FAR), a Guatemalan guerrilla movement, and the Sandinista National Liberation Front (FSLN) in Nicaragua, and in fact some CRAC activists joined the Guatemalan guerrillas in the late 1960s. They followed international events, particularly the mobilizations of students in France, Germany, and Mexico in 1968 and the Vietnam War, through multiple international publications that circulated

65. Rafael Velásquez, interview by Joaquín Chávez (March 22, 2007); Victoria Ramírez, interview by Joaquín Chávez (October 10, 2006).

66. Francisco Jovel, interview by Joaquín Chávez (April 18, 2007).

67. Ibid. 
clandestinely in El Salvador. Members of CRAC criticized the French Communist Party's negotiations with the French government in the aftermath of May 1968, which they viewed both as treason against the French unions and an expression of the Soviet policy of "peaceful coexistence" with the United States, which had grave consequences for revolutionary movements across the globe. They learned about the Tlatelolco massacre in Mexico City through the testimony of a Mexican professor of physics and mathematics who survived the killings and joined the University of El Salvador in 1968, only to be captured, disappeared, and assassinated by state agents in El Salvador the next year. ${ }^{68}$ They were also profusely informed about the Vietnam War and organized solidarity campaigns with North Vietnam and the National Liberation Front.

The emergence of CRAC was matched by a "cultural boom" at the university that featured the creation of literary movements, theater groups and rock and folk bands that incarnated the countercultural sensibilities of that period. ${ }^{69}$ Important figures of the New Left (including some Catholic Action members) were in fact musicians, writers, and poets. Some were members of folk music groups like La Banda del Sol (The Sun Band) and Mahucutah, and literary groups like La Masacuata (a composite noun of Nahuat origin that means "Deer Serpent"), El Papo Cosa Poética ("Papo" was slang for "papyrus," a type of paper used to roll marijuana cigarettes, thus "Papo Poetic Thing"), and La Cebolla Púrpura (The Purple Onion). While a careful discussion of the trajectories of these groups is beyond the scope of this article, it is fitting to note that like the Catholic Action intellectuals I discuss here they were also active participants in the formation of the New Left. For instance, La Masacuata, a literary movement and a semi-clandestine revolutionary group founded by Alfonso Hernández, Eduardo Sancho, and Carlos E. Rico Mira in San Vicente circa 1967 constituted the critical mass for the formation of the National Resistance (RN), a founding organization of the FMLN. In the late 1960s, La Masacuata was an eclectic group that organized "politico-literary lectures" to discuss the works of "Lenin, Marx, [the Spanish-Mexican philosopher Adolfo] Sánchez Vásquez, Mao, José Lezama Lima, the Latin American Boom, Salarrué [the Salvadoran writer Salvador Salazar Arrué], La Pájara Pinta [a literary journal published in San Salvador], Roque Dalton," and others. ${ }^{70}$

The music scene in San Salvador and other cities was splendid at that time. Poprock bands formed in this period blended U.S., British, and Mexican rock with sounds and lyrics that transpired the imagination, concerns, and artistic creativ-

68. Probably Luis Felipe Quezada.

69. Francisco Jovel, interview by Joaquín Chávez (April 18, 2007).

70. Jorge Vargas Méndez and J. A. Morasan, Literatura salvadoreña 1960-2000: bomenaje (San Salvador: Ediciones Venado del Bosque, 2008), p. 63 
ity of Salvadoran youth. Los Supersónicos, Los Kiriaps, Los Vikings, Los Lovers, Los Juniors de Santa Tecla, Los Mustangs, Los Intocables, and (later) La Fiebre Amarilla, Hielo Ardiente, and many other bands emerged during that time. While these musicians were not organically linked to the New Left or the countercultural movements at the university, some of them in fact echoed in subtle (and sometimes poetic) ways the social concerns of Salvadoran youth and occasionally joined forces with folk groups like La Banda del Sol. New Left activists and musicians like Carlos "Tamba" Aragón, the main composer and lead guitar player of La Banda del Sol, who later became a field commander in the FPL and died in combat at the start of the civil war, were also part of this musical scene. ${ }^{71}$ In 1971, the year that the New Left insurgents declared war on the oligarchic-military regime, the Salvadoran record label Estudio Doble V produced an anthology album called Unidad, which epitomized the sporadic cooperation between pop groups like La Fiebre Amarilla and Los Kiriaps and the folkloric La Banda del Sol. Aragón authored the emblematic song of that album called "El Planeta de los Cerdos" (Planet of the Pigs). The song deprecated the tyrannical ethos, corruption, demagoguery, and virtual submission to the U.S. government which it attributed to the high-ranking military officers who ruled the country, and anticipated an imminent uprising of Salvadoran youth inspired by "the light of love."72 According to Manuel Sorto (see Figure 2), a poet and artist who joined La Masacuata, this song

announced the ... rebellion of Salvadoran youth ... [it] was in its epoch a club blow against the owners of maces and the military governments in Central America, an explosion of energy and clarity in its lyrics ... the protest song ... of that youth in transition from hipismo [being hippies] to [becoming] guerrillas. ${ }^{73}$

In this period state agents often victimized with the same eagerness hippies, mariguaneros (marijuana smokers), and young women wearing jeans or short skirts, as well as poets, musicians, artists, and university activists whom they considered actual or potential insurgents. Clearly, from the perspective of the authoritarian regime, the countercultural movements, the student groups, and the New Left insurgency as well as some rock and folk bands, incarnated the subversive spirit of the Global Sixties in El Salvador.

The intensification of state repression against the rising social movements and opposition parties in the late 1960s radicalized Catholic Action students. The

71. See Manuel Sorto, "El Planeta de los Cerdos," ContraPunto: Noticias de El Salvador, October 31, 2009, http://www.archivocp.contrapunto.com.sv//la-anecdota/el-planeta-de-los-cerdos, accessed October 30,2013 .

72. Ibid.

73. Ibid. 
Figure 2

Armando Herrera, Manuel Sorto, Miguel Mármol, and Baltazar Polío, 1979

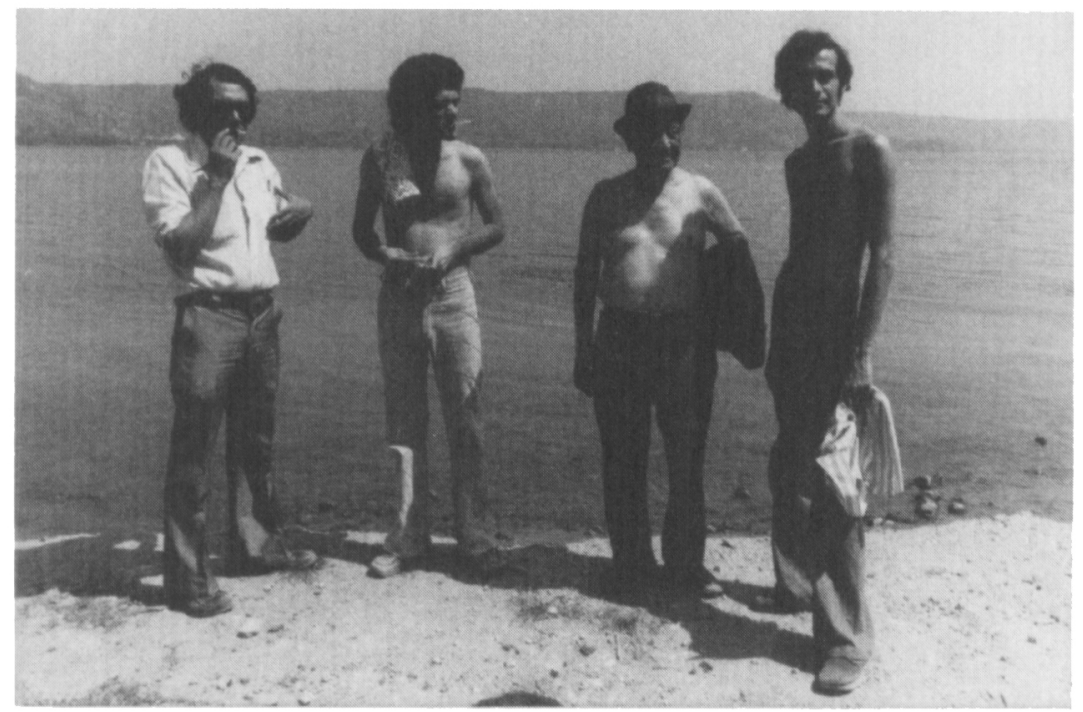

Left to right: writer Armando Herrera, artist and poet Manuel Sorto (a member of La Masacuata), the mythic Communist leader Miguel Mármol, and the filmmaker Baltazar Polío. According to Mármol, this was the exact place where the Communist Party of El Salvador was founded in 1930. Source: Photo taken by Raúl Cabrol in 1979 at the shores of Lake Ilopango. Courtesy of Manuel Sorto.

state crackdowns against the emerging teacher, worker, and student movements and opposition parties escalated significantly after 1967 as these forces seriously challenged the legitimacy of the PCN regime. At that time, the Partido de Acción Renovadora (PAR), a center-left party formed by independent leftist and PCS intellectuals, and the PDC had significantly increased their electoral results despite the climate of intimidation against opposition voters generated by the official party and the counterinsurgency apparatus.

Abraham Rodríguez, a cofounder of ACUS in 1949 and the Christian Democrat presidential candidate in the 1967, remembered that Alejandro Rivas Mira and Rafael Arce Zablah, two university students affiliated with the PDC and JEC respectively, and later the founders of insurgent organizations, witnessed the brutal tactics that ORDEN paramilitaries and the National Guard deployed against peasant voters in San Miguel during those elections. According to Rodríguez, Rivas Mira and Arce Zablah "were in tears" when they told him about these occurrences during a meeting they held in the aftermath of the elections. Rivas Mira plainly told Rodríguez that the only alternative left to 
Social Christians was to take up arms against the dictatorship. Rodríguez commented: "If our [Social Christian] youth were thinking about that [starting an armed movement], just figure what the communists were thinking at this time." ${ }^{74}$ In 1967, however, most communists were thinking about electoral politics, not armed struggle. Rivas Mira vanished from the university that year and traveled to East Germany and France. Little is known about his activities in Europe at that time, but apparently he, along with Venezuelan revolutionaries, participated in the 1968 insurgency in France. ${ }^{75}$ In 1969, Rivas Mira returned to El Salvador to form an urban guerrilla cell known as El Grupo ("The Group"), a predecessor of the ERP. ${ }^{76}$

In 1970, CRAC organized a major student strike to protest an ongoing academic crisis in Areas Comunes. At that time, the program evidenced high levels of student failure and repetition, which created widespread frustration among students. ${ }^{77}$ CRAC also orchestrated a "buffoon parade," a massive public protest that combined political critique and obscenity to ridicule the military government, the Catholic Church hierarchy, and even the country's beauty queen. This was probably the last public appearance of the former Catholic Action activists turned insurgents.

Between 1970 and 1972, leaders of CRAC founded several insurgent groups, which they called "politico-military organizations." A group led by Rafael Arce Zablah and Joaquín Villalobos created an armed organization they initially named Jaraguá, in reference to a resilient grass that grows in coastal areas in El Salvador and a peasant character in a novel by the Salvadoran writer Napoleón Rodríguez Ruiz who in Arce Zablah's view epitomized the purported rebelliousness of Salvadoran peasants. The Jaraguá group merged with survivors of El Grupo, the urban guerrilla cell founded by Alejandro Rivas Mira, university activists without previous political affiliation, and former members of the Communist Youth to form the ERP in 1971..$^{78}$ Arce Zablah (see Figure 3) became the most influential intellectual of this cohort. Circa 1973 he penned The Golden Grain, a Marxian analysis of the coffee economy in El Salvador that was widely studied by members of the New Left insurgency during the 1970 s and 1980 s. $^{79}$

74. Abraham Rodríguez, interview by Joaquín Chávez (December 27, 2006).

75. Sonia Aguiñada, interview by Joaquín Chávez (November 24, 2006); Ana Sonia Medina, inteniew by Joaquín Chávez (November 24, 2006).

76. Ibid.

77. See Diagnóstico global de la universidad, Tomo I, pp. 119-120, 125

78. Rafael Velásquez, interview by Joaquín Chávez (March 22, 2007); Sonia Aguiñada, interview by Joaquín Chávez (November 24, 2006).

79. See FLACSO El Salvador and Fundación “Dr. Manuel Gallardo," Prensa clandestina, pp. 19-45. 


\section{Figure 3}

Rafael Arce Zablah (“Amilcar"), leader of the ERP, circa 1974

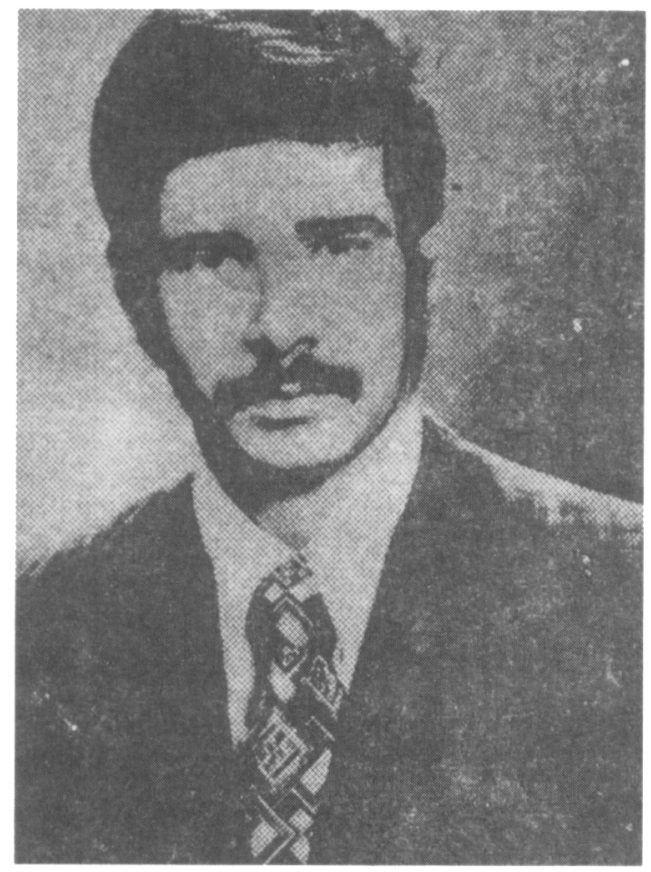

Source: Prensa Comunista, Fascismo y la Revolución Salvadoreña, special publication (circa 1974). Courtesy of CIDAI, Biblioteca P. Florentino Idoate, S.J. of the Central American University "José Simeón Cañas," San Salvador.

A group led by Felipe Peña Mendoza, initially known as El Movimiento de Izquierda Revolucionaria (The Left Revolutionary Movement, or MIR), joined Salvador Cayetano Carpio and other dissidents communists in 1970 to form a guerrilla organization that remained anonymous until 1972, when it adopted the name FPL Farabundo Martí after it attacked the Argentinean embassy in San Salvador to repudiate the execution of political prisoners perpetrated by that country's military near the city of Trelew in Chubut province, earlier that year. ${ }^{80}$

\section{THE NEW LeFT's “JuST WAR” (1972-1975)}

The leaders of the ERP and the FPL personified the blending of the Catholic anti-capitalist thought that emerged in El Salvador at the time of the Second

80. Atilio Montalvo, interview by Joaquín Chávez (November 6, 2006); and Marta Harnecker, Con la mirada en alto: historia de las FPL Farabundo Martí a través de sus dirigentes (San Salvador: UCA Editores, 1993), p. 15. 
Vatican Council, the intellectual production and revolutionary experiences of the Latin American Left, and various Marxist-Leninist traditions, particularly Vietnamese Marxism in the case of the FPL and Maoism in that of the ERP. They were also cognizant of European New Left thought as formulated by Herbert Marcuse, Nicos Poulantzas, Louis Althusser, Daniel Cohn-Bendit, and others. The social Catholic thought incarnated by ERP and FPL leaders formerly affiliated with Catholic Action (and CRAC) enabled the formation of long-lasting alliances between the New Left and peasant movements in Chalatenango, San Vicente, and Morazán, which constituted the backbone of the Salvadoran insurgency in the 1970s and throughout the civil war. However, this was not the typical case of the "unblocking of the peasants' consciousness" promoted by urban intellectuals; arguably, peasant leaders in those areas were already "politicized" by the time insurgents like Peña Mendoza and Arce Zablah first visited those regions in the early $1970 \mathrm{~s}^{81}$ It was, instead, a dialogical process between urban insurgents, peasant leaders, and progressive Catholic priests that constituted a frontal challenge to the conservative Catholicism and the counterinsurgency apparatus that prevailed in the countryside in the $1970 \mathrm{~s} .{ }^{82}$

The New Left insurgency sought to reinterpret the relation between religion and politics by bringing to the fore the Christian doctrine of the "Just War," particularly in the case of the FPL. The Catholic background of the organization's top leadership informed its perspective on this matter. The FPL publicly acknowledged the crucial role that Christians played in revolutionary politics and envisioned the formation of an alliance among priests, Catholic communities, and the insurgency. ${ }^{83}$ In 1975, it dedicated an entire edition of La Estrella Roja ("The Red Star"), the organization's theoretical publication, to explicate its Marxist-Leninist politics and ideology to "progressive priests." ${ }^{4}$ "The Red Star 2," as the document is known, stressed the legitimacy of revolutionary violence to combat the oligarchic-military regime and to create a humane and just society, borrowing from the Christian doctrine of the Just War. It cited verbatim Pope Paul VI's encyclical Populorum Progressium to make this point: ${ }^{85}$

It is possible also that some might think that our revolutionary discipline (and even our revolutionary practice) does not duly consider the human character of the popular struggle. We believe that such a view would not match reality. All our activity

81. See Carlos Rafael Cabarrús, Génesis de una revolución: análisis del surgimiento y desarrollo de la Organización Campesina en El Salvador (Mexico: Ediciones de la Casa Chata, 1983), pp. 141-163.

82. Chávez, "The Pedagogy of Revolution," pp. 163-183. 30 .

83. "Popular Liberation Forces-FPL Farabundo Martí," Estrella Roja 2, February 11, 1975, pp. 21-

84. Ibid., p. 1.

85. Ibid., pp. 9-12. 
aims at radically changing the situation of injustice, exploitation, and lack of humanism [sic] endured by the majority of workers. We are aware that such injustice can only be definitively liquidated through the deepening and intensification of the class struggle of the exploited to liberate themselves from the oppression and exploitation of the ruling classes. And the revolutionary violence of the masses is the crucial factor that will break the chain of oppression, vis-à-vis the stubborn resistance of the ruthless exploiters who are not willing to abandon their privileges and domination, neither through reasoning nor through appeals to their goodness, "charity," humanism, and religious beliefs. In this sense, we remember the acknowledgment of this fact contained in Pope Paul VI's encyclical Populorum Progressium when it says [sic] that revolutionary violence is justified "in case of evident and prolonged tyranny, which gravely threatens the fundamental right of the person and dangerously damages the common good of the country." 86

While the FPL has been often represented as the quintessential MarxistLeninist organization of the Salvadoran revolution, it also featured an influential Catholic tradition embodied by former Catholic Action students like Felipe Peña Mendoza, dissident Jesuits, diocesan priests, nuns, Catholic peasant leaders, and laypeople. A similar argument can be made in the case of the ERP if we consider the Catholic background of some of its most prominent leaders, among them Rafael Arce Zablah, Joaquín Villalobos, Ana Sonia Medina, and others, as well as the multiple alliances this organization forged with Catholic priests, nuns, and Catholic communities in both rural and urban areas. ${ }^{87}$

\section{CONCLUSION}

Former affiliates of Catholic Action played fundamental roles in the creation of the New Left insurgency in El Salvador. In contrast to scholarship that has emphasized the participation of dissident communists and Christian Democrats in this process, the evidence presented here suggests that the ACUS-JEC cohort that came of age between 1967 and 1972 constituted a key component in the rising New Left. Multiple ideological, political, and cultural trends in the 1960s shaped this rupture generation, chiefly the Catholic anti-capitalist thought I have discussed here, dependency theory, and the revolutionary politics of the Latin American Left. In many ways, this group crystallized the rich eclecticism of the Global 1960s into innovative revolutionary theories and strategies that enabled the creation of one of the most potent insurgencies in twentieth-century Latin America, namely the FMLN.

86. Ibid, pp. 9-10.

87. Joaquín Villalobos, "Homenaje a Rafael Antonio Arce Zablah," El Diario de Hoy, Seprember 28, 2005 . 
ACUS-JEC affiliates turned revolutionaries ultimately succeeded at what most urban radicals in Latin America in this period failed to do: create strategic alliances with peasant movements, which made up the core of the insurgency during 1970 s and throughout the civil war. As the reformist promise of the Alliance for Progress waned and the counterinsurgent state increasingly persecuted opposition parties like the PDC and PAR, the rising social movements, and dissident youth-especially after the 1967 presidential electionACUS and JEC affiliates became leaders of CRAC, the radical student movement that emerged at General Studies at the time of the university reform. CRAC leaders formed clandestine revolutionary groups like Jaraguá and MIR, which became the predecessors of the ERP and FPL respectively. Drawing on Catholic social thought and the Christian doctrine of the "Just War," leaders of the New Left insurgency built long-lasting alliances with peasant communities in Morazán, Chalatenango, San Vicente, and other rural areas, and in doing so transformed this movement into a formidable political and military force that posed an unparalleled threat to oligarchic-military rule and U.S. hegemony in El Salvador.

Based on his examination of the 1968 student mobilizations in Mexico, Brazil, and Uruguay, Jeffrey Gould posits that authoritarian governments in those countries repressed student and working-class movements before sectors of the New Left formed insurgencies in response to the escalating state terror ${ }^{88} \mathrm{He}$ criticizes ex post facto explanations of the origins of the New Left insurgencies that omit a close examination of the trajectories of these movements and instead project "findings and analysis from other parts of the World onto Latin America," wrongly blaming the New Left for provoking state terror and undermining the Old Left's democratizing potential. Gould deems that state repression debilitated both the New Left and the Old Left and radicalized popular politics in Mexico and the Southern Cone after $1968 .^{89} \mathrm{My}$ analysis of the radicalization of Catholic Action students in El Salvador reinforces Gould's perspective on this issue. Systematic state crackdowns against opposition parties, social movements, and dissident intellectuals that began in the early $1960 \mathrm{~s}$ prompted the rise and rapid expansion of the New Left insurgencies, not vice versa ${ }^{90}$ Counterinsurgency ultimately created an internal enemy through its relentless persecution of the democratic movements formed in El Salvador in the 1960s and 1970s: its actions motivated dissidents of the PDC and PCS,

88. Jeffrey L. Gould, "Solidarity Under Siege: The Latin American Left, 1968," Anerican Historical Review 114:2 (April 2009), pp. 348-375.

89. Ibid., p. 374.

90. According to Grenier, the New Left insurgency provoked the escalation of state terror in El Salvador. See Yvon Grenier, The Emergence of Insurgency in El Salvador, pp. 2, 35-66, and 160-161. 
leaders of social movements, and Catholic Action intellectuals, as well as youth affiliated with countercultural groups, to join or support the insurgency. ${ }^{91}$

In 1968 Shafik Handal, a leader of the PCS, asserted that a crucial feature of the Latin American left in the 1960s was the massive integration of "the middle sectors" (that is, employees, professionals, students, and teachers) into new revolutionary organizations that challenged the traditional leadership roles of communist parties in countries across the region. ${ }^{92}$ Handal favored an open ideological debate with these rising forces, which he termed "leftists," or the "naive left," but he also warned communist leaders in Latin America not to blame them for "throwing a windfall of doubts over old truths" because "life itself ... is unfolding in unexpected directions, very different from those foreseen in our conceptions. " ${ }^{93}$ While Handal explicitly defended the legitimacy of revolutionary violence in Latin America, he also chastised what he called "the infantile radicalism" of the New Left. He argued that the massive incorporation of "middle sectors" into the New Left "had revived many features of anarchism and populism," and deemed this process an obstacle for Latin American revolutions. ${ }^{94}$

The poet Roque Dalton relinquished his affiliation to the PCS circa 1968 due to the party's ambiguous and ambivalent stance on armed struggle and electoral politics. He joined the ERP in 1973, only to be murdered in May 1975 by a militaristic faction that commanded this group at the time. Like many other New Left intellectuals in El Salvador, Dalton objected to the PCS critique of the guerrilla movements at the meeting of the Organization of Latin American Solidarity (OLAS) held in Havana in August 1967, and to the party's rejection of Che Guevara's foco principles, published the same year. Dalton's resignation from the PCS, his endorsement of armed revolution in Latin America, and his (tragic) integration into the ERP epitomize the schism between the Old Left and the New Left in El Salvador.

While the ERP and the FPL developed different ideologies and politics, both produced rigorous critiques of PCS reformism, particularly of its continued participation in electoral politics, which they deemed a legitimatization of the electoral frauds and repression conducted by the PCN governments in the 1970 s. They also wrote theoretical works to disprove the PCS analyses of Sal-

91. See Joaquín M. Chávez, "The Construction of the Internal Enemy: Pondering the Legacies of U.S. Anticommunism, Counterinsurgency, and Authoritarianism in El Salvador, 1952-1981," in Hearts and Minds: A People's History of Counterinsurgency, Hannah Gurman, ed. (New York: The New Press, 2013).

92. Shafik Jorge Handal, "Reflexiones sobre los problemas de la Revolución Latinoamericana," mimeographed (San Salvador, 1968), p. 3.

93. Ibid., pp. 1-4.

94. Ibid., pp. 11-17. 
vadoran economy, society, and politics. The cultural, political, and ideological gap between PCS and New Left intellectuals became a dominant characteristic of the Salvadoran left during the 1970s and 1980s.

The vital contributions of social Catholicism to the formation of the New Left ethos in El Salvador deserves serious reflection, as it conferred on this movement a distinct ideological endurance and potent organizational capabilities during the intensification of state terror in the 1970s and the civil war that devastated the country between 1980 and 1992.

University of Illinois, Chicago

JOAQUIN M. CHÁvEZ

Chicago, Illinois 